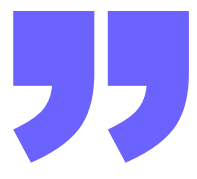

\title{
SEMIOTICS ANALYSIS OF SYMBOL (EMOJI) THAT FOUND IN THE CAPTIONS OF @BRIANIMANUEL INSTAGRAM ACCOUNT
}

\author{
Roikhatul Jannah ${ }^{1}$, Putu Devi Maharania ${ }^{2}$, I.B. Gde Nova Winarta ${ }^{3}$ \\ Mahasaraswati Denpasar University, Indonesia ${ }^{1,2,3}$ \\ roikhannah1@gmail.com, \\ gusdnova@gmail.com \\ devmaharani86@gmail.com,
}

\begin{abstract}
The study is focused on find out the total amount of symbol (emoji) and the meaning of symbol (emoji) that found in the captions of @brianimanuel Instagram account. This study is used theory proposed by Charles Sanders Peirce about semiotic and used semiosis process. This study took the data from the captions of @brianimanuel in his Instagram Post that used emoji from 27 Sept 2019 - 15 Feb 2021. In this study, the writers used observation procedure descriptive-qualitative method for analyzing the data. In addition, for presented the data, the writer used an informal method. This study found there are 73 total amount of emoji and 73 meaning of symbol (emoji) that found in the 55 captions of @brianimanuel in his Instagram Post.
\end{abstract}

Communication, Social Media, Instagram, Young Generation, Emoji, Semiotics 


\section{INTRODUCTION}

Communication is the important thing for people because with communication people could connect from person to others, share their thought, feeling and more. People are communicated both in speaking and writing. In writing, now people are connected from around the world with mobile phone. With mobile phone, we could send a message to other, and it is categorized as electronic communication. Texting message is used to send message and it is famous in the past but now people tend to use social media rather than texting message.

Social media is available in smartphone and connected with internet. According to Bergstrom \& Backman cited in Ting et al (2015: 16), in modern society social media plays the important role in individual and organizational. Social media become a main tool in personal and organizational activities because the growth of communication technologies (e.g. Internet and smartphone). Social media is the platform which useful for human being. In social media, we could share many things such as send the message, share the picture and video, share the location and more. One of the social media which famous in this era is Instagram.

Instagram is the social media application which available in Application Store and Google Play in smartphone which found in 2010 (Bergstrom \& Backman cited in Ting et al, 2015: 16). In Instagram, people could send or share the story, the picture and video including the caption. We could comment the post and send the direct message. The majority users in Instagram is young generation. Abott et al; Salomon cited in Ting et al (2015: 18) report in social networking services the application which reaches the younger generation and appeals to diverse societies is Instagram.

In social media people tend to use non formal language and used emoji in daily interaction. Emoji is the evolution from emoticon which came from smiley. Smiley regarded as first expression symbols and it is found in 1960s. The yellow face with eyes and wide grin which printed on buttons, brooches and t-shirt is smiley. Smiley is famous and appear as a permanent of western culture in 1980s (Stark and Crawford cited in Bai Q et al, 2019: 2). According to Dimsom (cited in Bai $Q$ et al 2019: 4) in Unicode there were 3,019 emoji and emoji appear in half of all text messages on Instagram and in Facebook emoji is used daily by 5 billion users. Emoji have some functions, and it is having a big role in social media. The symbol which has Unicode and used to represent facial expressions, abstract emotion and describe animals, plants, activities, gestures and object is emoji (Rodrigues et al cited in Bai Q, 2019: 4). Brian Imanuel Soewarno or known as Rich Brian is a rapper who actives in Instagram with the username account @brianimanuel. He often shares his 
schedule tour, his song and his activities for his fans there. In his Instagram he often uses emoji in the captions of his Instagram post.

Emoji which appear on social media is categorized as symbol which learned in semiotics. Based on the explanation above, the researchers are interested to analyze about emoji or symbol in semiotics field. This research aimed to find out the total amount of symbol (emoji) and the meaning of symbol (emoji) that found in the captions of @brianimanuel Instagram account. It helped the researchers and readers to expand the knowledge about symbol in semiotics field and to understand the meaning of the emoji which appear in the caption post in Instagram.

The similar study in form of an article was found with title Semiotik Lambang Emoji Pada Status dan Komentar Facebook Mahasiswa Pendidikan Bahasa Indonesia. The study was done by Asnidar (2019). The data were taken from Indonesian Language Education Department students. The study is focused on how emoji is used on Facebook status and comments by Indonesian Language Education Department students. The writer used descriptive - qualitative research. The writer found that most of emoji are used in Facebook status and comments and the use of emoji by Indonesian Language Education Department students are not noticed the meaning which contained in emoji.

The second study was proposed by Eriana. (2015) with title Peirce's Semiotics Analysis of Icon and Symbol on Perfume Advertisements. The study is focused to find out the meaning of signs on perfume advertisements and to explain its semiosis processes. The data were taken from perfume advertisements on Sephora site (www.sephora.com). The study used descriptive-qualitative research. In the finding, the writer found there are 194 perfume advertisement from 29 brands which used English and also 29 icons and 23 symbols from 29 advertisements. The researcher also found that the picture (icon) can be the first aspect that can give the direction to the meaning, then the language which is used in the advertisement (symbol).

Another study in form of thesis which proposed by Purnomo. (2018) entitled Analisis Semiotika Terhadap Penggunaan Emoticon WhatsApp Dalam Komunikasi Interpersonal Antar Mahasiswa Ilmu Komunikasi Angkatan 2013. The study aimed to determine the meanings contained in the emoticons used in communicating media of WhatsApp. The writer used qualitative method. This study used the theory from Charles Sanders Peirce to see the meaning contained in emoticons. In the finding, the writer found several reasons of user used emoticons; to reinforce the message content, provide support, quip someone, express the feelings of sadness, shame, encourage, apologize, disappointment and gratitude. The use of WhatsApp emoticons should not be used unwisely. Emoticon which is used carelessly will cause misinterpretation of the message 
meaning sent and can cause conflict among users of WhatsApp application.

\section{METHODS}

The data were taken from Instagram Post of @brianimanuel. The writer chose posts from 27 Sept 2019 - 15 Feb 2021 and took the data from the caption's post that used symbol (emoji). This study is aimed to find out the total amount of the symbol (emoji) in the captions and used theory proposed by Charles Sanders Pierce to find out the meaning of the symbol (emoji) that found in the captions of @brianimanuel Instagram account. In collected the data, the writers used observation procedure method which use several steps before analyzed the data. After collected the data, the writers used descriptive-qualitative method to analyze the data. In addition, this study is used an informal method to show the data, which used an explanation about the finding of this study. This study used Charles Sanders Peirce theory about semiotics to find out the meaning of symbol (emoji) that found in the data source.

Semiotics is branch of linguistics which learned about the sign. The science study of sign in form of device or symbols that used by people in communication is semiotics (Henny cited in Ibrahim \& Sulaiman, 2020: 24). Other definitions were come from several experts about semiotics cited in Ibrahim \& Sulaiman (2020: 25) "The word semiotics itself comes from the Greek semeion which means sign (Sudjiman and Van Zoest, 1996), or seme which means interpreter of sign (Cobley and Jansz, 1999), or what is commonly understood as a sig by which something in known or a sign where something can be known (John Lock, 1960)". Based on Charles Sanders Peirce cited in Eriana (2015: 3), semiotics has 3 aspects they are representamen, object, and interpretant. The 3 aspects are called semiosis.

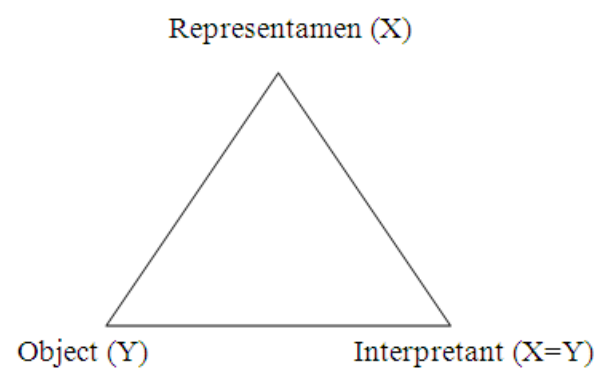

Figure 1. The Semiosis Aspects

source: https://www.muradmaulana.com/2016/09/mengenal-pemikiran-charles-sanders.html

Representamen is the sign or the thing that stand for something to somebody in some respect or capacity, while the thing which referred is object and the relation between representamen and object is interpretant 
(Peirce cited in Eriana, 2015: 19). For example, the word book is representamen, the physically book is object and interpretant is the idea or reflection when person hear or imagine book such as knowledge, writing, learning and more. "a Sign or Representamen is a First which stands in such a genuine triadic relation to a Second, called its Object, as to be capable of determining a Third, called its Interpretant, to assume the same triadic relation to its Object in which its stands itself to the same Object. The triadic relation is genuine, that is its three members are bound together by it in a way that does not consist in any complexus of dyadic relations. That is the reason the Interpretant or Third, cannot stand in a mere dyadic relation to the Object, but must stand in such a relation to it as the Representamen itself does (Peirce, 1940: 99)". Based on the explanation from Charles Sanders Peirce, there is showed that the three members of semiosis (representamen, object, interpretant) are the unity which have their functions and must stand together. Three members of semiosis (representamen, object, interpretant) have their own classification:

Table 1 Semiotic classification by Peirce

\begin{tabular}{c|ccc} 
Representamen & Qualisign & Sinsign & Legisign \\
\hline Object & Icon & Index & Symbol \\
\hline Interpretant & Rheme & Dicent & Argument
\end{tabular}

The classification of object that is symbol is the possible research which to do in this study because the limitation of the problem and another classification need deeper research. According to Peirce (1940: 102) a sign that refers to an object which represented of law and general thought for interpreted the sign as referring to that object is called symbol. The symbol which analyzed in this study is emoji. Based on emojiall.com there are 1816 emoji, and those emoji are divided into 10 types, they are smileys \& emotion, people \& body, component, animals \& nature, food \& drink, travel \& places, activities, objects, symbols, and flags.

\section{RESULTS}

\section{RESULTS AND DISCUSSION}

This part is presented the summaries of the finding in this study. This study is analyzed 55 Instagram Post from @brianimanuel. In some post there are some captions that used symbol (emoji). In 55 Instagram Post there are 73 total amounts of emoji are found.

\section{DISCUSSION}

The data is presented by the diagram of semiosis process to find out the meaning of the symbol (emoji) which appear in the captions of the 
Instagram Post. In this section some data are explained by paragraph. It is explained below:

\title{
Data 1:
}

\author{
“Thank u Paris $\square$ ” \\ (27 November 2019, @brianimanuel)
}

Based on Peirce's theory, emoji $\square$ is the representamen of symbol (R). Then based on online dictionary emojiall.com emoji handshake express agreement, cooperation, and greeting. The connection between representamen and object creating the interprentant (I) if $\square$ is emoji handshake and in the caption this emoji used to express the feeling of cooperation.

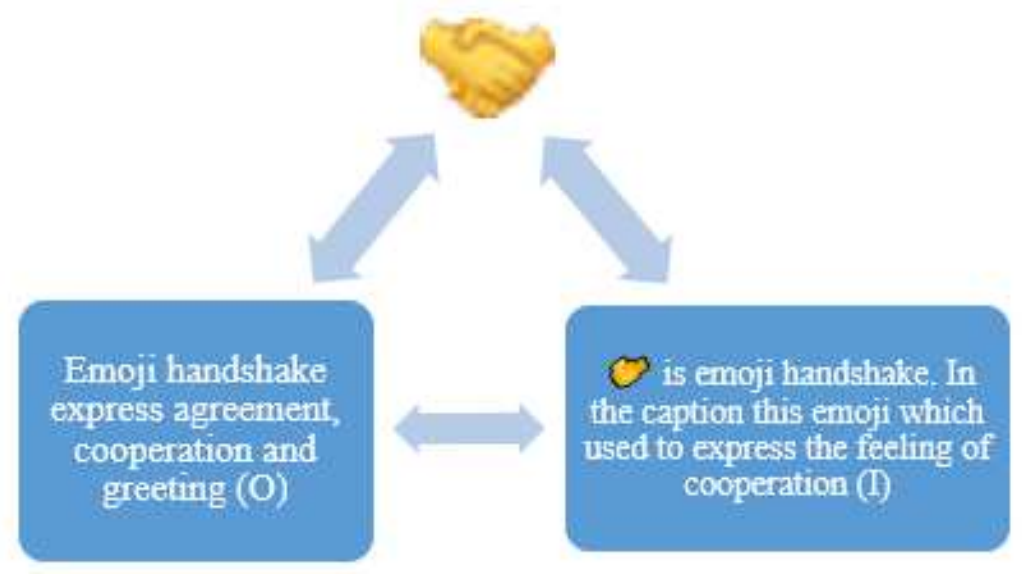

Figure 2. Handshake Emoji

Rich Brian is held the music concert in Paris then posted his picture in Paris on Instagram. In the caption of his Instagram Post on 27 November 2019 Rich Brian is wrote "Thank u Paris $\square$ ". The meaning of emoji $\square$ in Rich Brian's caption express is he feels Paris gave positive vibes and his crew have made him grateful and joy because he could hold event the music concert in Paris.

\section{Data 2:}

"Europe I'm coming to U!! Tickets on sale now: richbriantour.com if you don't come ur a fuckin hot dog (22 September 2019, @brianimanuel)

According to Peirce's theory about semiosis process, emoji $\Lambda$ is the representamen of symbol (R). Online dictionary emojiall.com explained the emoji sailboat refers to sailing sports or sailing entertaining $(\mathrm{O})$. The representamen $(\mathrm{R})$ and object $(\mathrm{O})$ creating the interpretant $(\mathrm{I})$ if $\underline{\Lambda}$ is emoji sailboat and in the caption, it is an emoji which used for refers sailing sailing entertaining. 


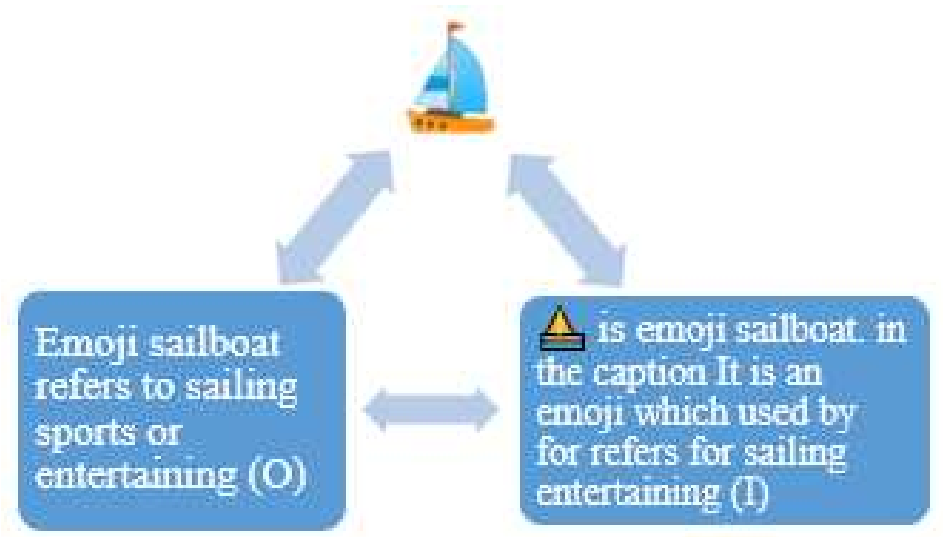

Figure 3. Sailboat Emoji

On 22 September 2019 Rich Brian is wrote “Europe I'm coming to U!! Tickets on sale now: richbriantour.com if you don't come ur a fuckin hot dog $\Lambda$ " in the caption of his Instagram Post. The caption is informed to the reader about the ticket of his concert in Europe. Emoji $\Lambda$ in Rich Brian's caption meant his concert music which named "sailor tour" and the emoji also used to express his music tour which sail around Europe.

\title{
Data 3:
}

\author{
"Happy valentine's day fart eater $\square$ " \\ (15 February 2021, @brianimanuel)
}

In Peirce's theory, emoji $\square$ is the representamen of symbol (R). Then according to online dictionary emojiall.com, the emoji kiss mark represents romance and enthusiasm and indicate kissing $(\mathrm{O})$. The connection between representamen and object creating the interpretant (I) if $\square$ is emoji kiss mark and this emoji is used by someone for represent romance and enthusiasm and indicate kissing.

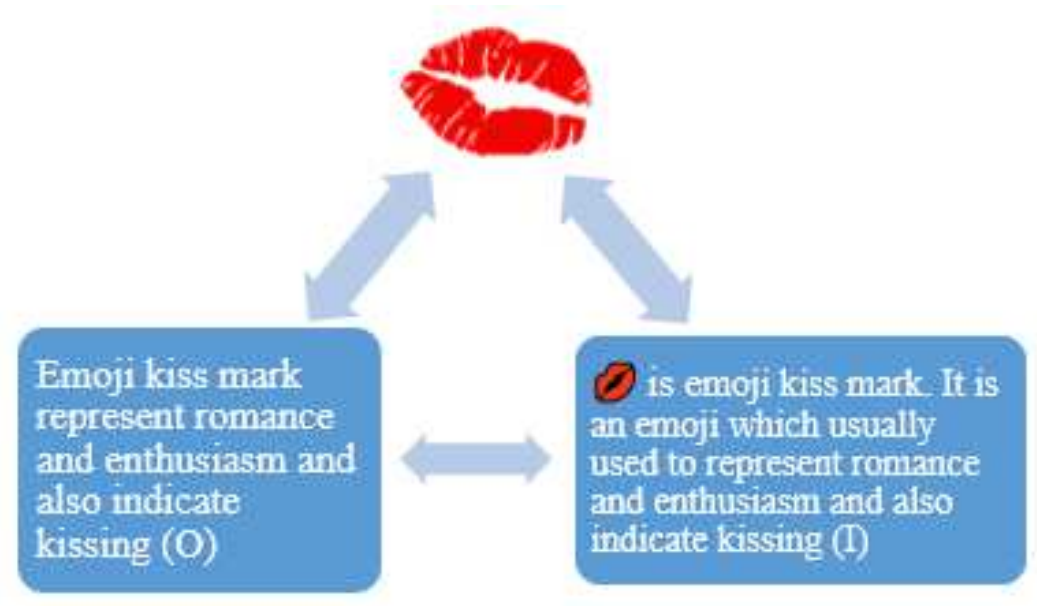

Figure 4. Kissing Emoji 
Rich Brian posted the picture of him and his girlfriend on 15 February 2021. In the caption he is wrote "Happy valentine's day fart eater ". In the caption he called his girlfriend "fart eater" with emoji which showed his love. The meaning of emoji in Rich Brian's is kissing which express the romance between him and his girlfriend @vanteyy in valentine day.

\section{Data 4:}

"Thinkin about cutting my own hair. Yes or no $\square$ "

(2 April 2020, @brianimanuel)

In semiosis process, emoji is the representamen of symbol (R). Then based on online dictionary emojiall.com, the emoji hedgehog represents an animal hedgehog itself and used to describe people who are alert and hard to accessible like hedgehog $(\mathrm{O})$. The interpretant $(\mathrm{I})$ which shown from the connection between representamen and object is is emoji hedgehog and this emoji is used by someone for represent an animal hedgehog itself.
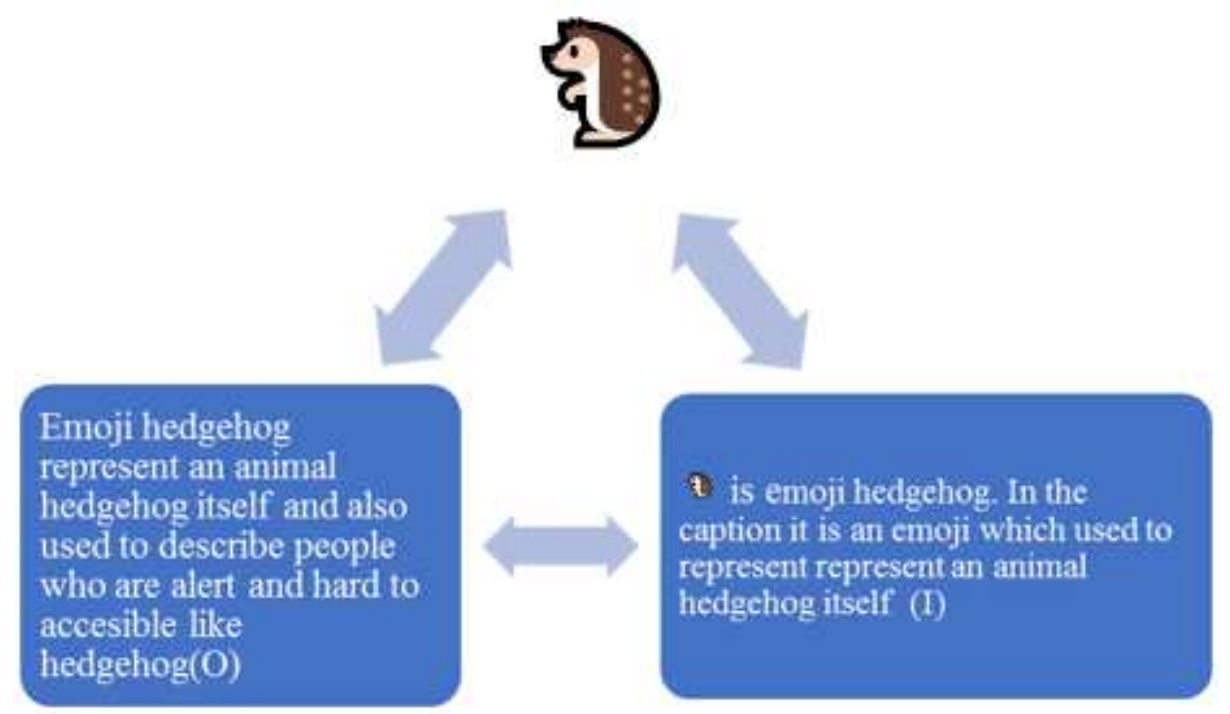

Figure 5. Hedgehog Emoji

In 2 April 2020, Rich Brian posted the picture in his Instagram. He is posted his selfie with the caption "Thinkin about cutting my own hair. Yes or no "The picture is showed his hair which looks spiny and emoji in Rich Brian's caption is as representament of Rich Brian's hair which looks spiny like hedgehog spine.

\section{Data 5:}

"Happy father's day to the man who gave me all of the life lessons that made me who I am today. He is very cool. Love u

(22 June 2020, @brianimanuel) 
According to Peirce's theory, in semiosis process the representamen of symbol $(\mathrm{R})$ is $\mathrm{D}$ Based on online dictionary emojiall.com, a red heart which refers to like, love, and romance and used to express love for lovers is emoji red heart $(\mathrm{O})$. The interpretant $(\mathrm{I})$ of representamen $(\mathrm{R})$ and object (O) is Cis an emoji red heart which used to express like, love and it is also used by someone to express love for someone.

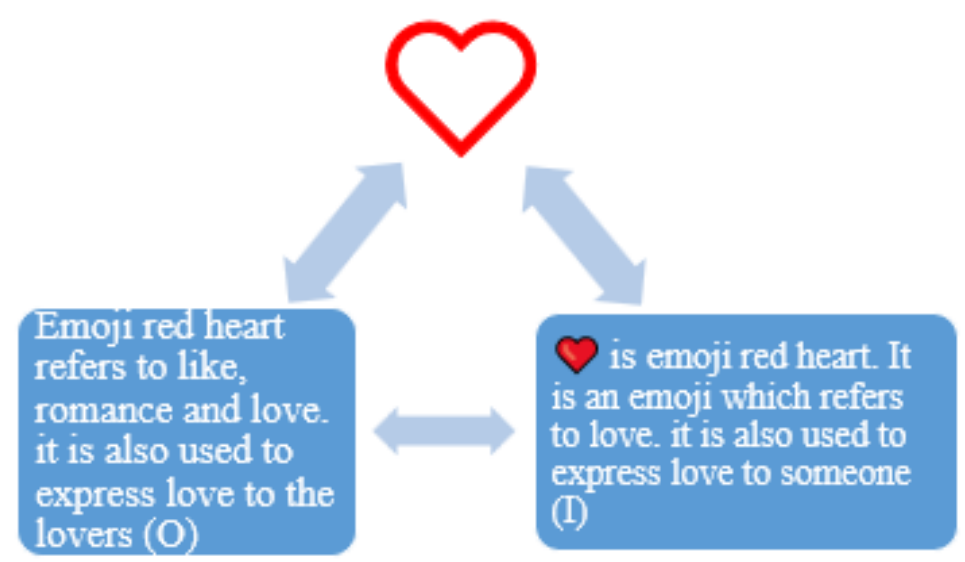

Figure 6. Heart Emoji

Rich Brian's father was birthday on 22 June 2020. Rich Brian is posted the picture of his childhood with his brother and father and wrote the caption "Happy father's day to the man who gave me all of the life lessons that made me who I am today. He is very cool. Love u $P$ in his Instagram. In the caption there is an emoji @which meant the feeling of Rich Brian. He feels proud with his father and that emoji express his love to his father.

\section{CONCLUSION}

In this era, social media is online communication which used by people around the world. Social media is available in smartphone and computer and connected by internet. One of social media platform which famous now is Instagram. In Instagram people could send or share the story, the picture and video including the caption. We could comment the post and also send the direct message. In social media people tend to use non formal language and used emoji in daily interaction. Emoji is the symbol which used in writing communication for express body language or gesture, represent the object and help to show the emotion of the writer. Emoji which appear on social media is categorized as symbol which learned in semiotics. Semiotics is branch of linguistics which learned about the sign or symbol. Based on Charles Sanders Peirce cited in Eriana (2015: $3)$, semiotics has 3 aspects they are representamen, object, and interpretant. The 3 aspects are called semiosis. This study is aim to find 
out the total amount of emoji and analysed the meaning of the symbol (emoji) that found in @brianimanuel caption in his Instagram Post.

Based on the finding in this study, there are 73 total amount of the emoji and 73 meaning of symbol (emoji) that found in 55 captions of @brianimanuel in his Instagram Post.

The writers hope that this study is useful and helpful for the reader or the other researcher to understand and expand the knowledge about semiotic analysis.

\section{REFERENCES}

Asnidar, A. 2019. Semiotik Lambang Emoji Pada Status dan Komentar Facebook Mahasiswa Pendidikan Bahasa Indonesia. Article. Makassar: Muhammadiyah of Makassar University.

Bai, Q., Dan, Q., Mu, Z., Yang, M. 2019. A Systematic Review of Emoji: Current Research and Future Perspectives. Frontiers in Psychology. 2019, Vol 10 Article 2221.

Brianimanuel. Retrieved 7th June 2021, from https:/ / www.instagram.com/brianimanuel/ ?hl=id

Emojiall.com. Retrieved 11th June 2021, from https://www.emojiall.com/en

Eriana, A. 2015. Peirce's Semiotics Analysis of Icon and Symbol on Perfume Advertisements. Thesis. Jakarta: English Letter Department Letters and Humanities Faculty State Islamic, Syarif Hidayatullah University.

Ibrahim., Sulaiman. 2020. Semiotic Communication: An Approach of Understanding A Meaning in Communication. International Journal of Media and Communication Research. 2020. Vol 1, 22 32.

Maulana, M. 2019. Retrieved 3rd July 2021, from https:/ / www.muradmaulana.com/2016/09/mengenalpemikiran-charles-sanders.html

Peirce, C. S. 1940. Philosophical Writings of Peirce Selected and Edited with an Introduction by Justus Buchler. New York, Dover Publications Journal of Computer - Mediated Communication. $2009,14,1108-1129$.

Purnomo, A. C. 2018. Analisis Semiotika Terhadap Penggunaan Emoticon WhatsApp Dalam Komunikasi Interpersonal Antar Mahasiswa Ilmu Komunikasi Angkatan 2013. Surakarta: Communication Study Program Faculty of Communication and Informatic, Muhammadiyah University of Surakarta.

Ting, H., Ming, W. W. P., Run, E. C. D., Choo, S. L. Y. 2015. Beliefs about the Use of Instagram: An Exploratory Study. International Journal of Business and Innovation. 2015, Vol 2; No 2, 15-31. 